\title{
Development and control of caries lesions on the occlusal surface using a new in vivo caries model
}

\section{Desenvolvimento e controle de lesões de cárie sobre a superfície oclusal usando um novo modelo de cárie in vivo}

\author{
Susana Paim* \\ Adriana Modesto** \\ Jaime Aparecido Cury*** \\ Anders Thylstrup****
}

\begin{abstract}
The aim of this study was to develop a new in vivo caries model for the occlusal surface and to describe the enamel features observed before and after dental plaque control (DPC). Four volunteers (12-15 years old) participated in the experiment, each of which was due to have 2 homologous first premolars extracted for orthodontic reasons. Test surfaces did not present visible signs of demineralization, opacities or fillings. A wire mesh was used to promote dental plaque accumulation on the occlusal surface. After 4 weeks, the wire mesh was removed and DPC was performed. In Groups 1 and 2, DPC was performed by the subjects daily and, in Groups 3 and 4, DPC was performed by the subjects daily and by the professional weekly. One tooth/pair of Groups 1 and 3 was extracted after 2 weeks. One tooth/pair of Groups 2 and 4 was extracted after 4 weeks. All test surfaces showed demineralization after the wire mesh was removed. The observed re-establishment of the enamel brightness was directly related to the increase of the DPC duration. In polarized light microscopy, interindividual differences varying from pseudoisotropic areas to enamel lesions were noted in specimens submitted to 2 weeks of DPC. Specimens submitted to 4 weeks of DPC showed less tissue porosity. It was concluded that the new in vivo caries model was effective since all occlusal surfaces presented clinical and microscopic signs of mineral loss in different stages after 4 weeks of cariogenic challenge. After DPC on the test surfaces, there was a reduction of mineral loss suggesting control of demineralization on these surfaces.

DESCRIPTORS: Dental fissures; Dental caries; Microscopy, polarization.
\end{abstract}

RESUMO: O objetivo deste estudo foi desenvolver um modelo de cárie in vivo para superficie oclusal e descrever as características do esmalte observadas antes e após o controle mecânico de placa dental (CMPD). Quatro voluntários (12-15 anos) participaram do experimento, contribuindo com um par de pré-molares homólogos, com indicação de extração por motivos ortodônticos, sem sinais visiveis de desmineralização, opacidades nem restaurações. Uma tela metálica colocada sobre a superfície oclusal propiciou acúmulo microbiano. Após 4 semanas, removeu-se a tela e a superficie foi submetida ao CMPD. Nos Grupos 1 e 2, o CMPD foi realizado pelo individuo diariamente e nos Grupos 3 e 4 diariamente pelo indivíduo e semanalmente pelo profissional. Os dentes dos Grupos 1 e 3 foram extraídos após 2 semanas, e os dos Grupos 2 e 4, após 4 semanas de CMPD. Após a remoção da tela, foram visíveis diferentes graus de desmineralização em todas as superfícies-teste, e a recuperação do brilho foi diretamente proporcional ao tempo de CMPD. Microscopicamente, foram notadas diferenças interindividuais como áreas pseudo-isotrópicas até lesões em esmalte, após 2 semanas de reexposição ao CMPD. Uma menor porosidade tecidual foi encontrada nos espécimes submetidos a 4 semanas de CMPD. Concluiu-se que o modelo de cárie in vivo desenvolvido foi efetivo, visto que todas as superficies oclusais apresentaram sinais clínicos e microscópicos de perda mineral em diferentes graus, após 4 semanas de desafio cariogênico. Após a reexposição das superficies-teste ao CMPD, notou-se uma redução das perdas minerais que foi sugestiva do controle da desmineralização nessas superficies.

DESCRITORES: Fissuras dentárias; Carie dentária; Microscopia de polarização.

\section{INTRODUCTION}

The development of the natural caries lesion is a dynamic, gradual and intermittent process, where individual factors such as enamel structure, saliva composition, oral hygiene, presence of fluoride and other variables may interfere in the lesion's development ${ }^{11}$. Due to this variability, the

\footnotetext{
*Assistant Professor, Pediatric Dentistry Area, State University of Feira de Santana.

**Associate Professor, Department of Pediatric Dentistry and Orthodontics, School of Dentistry, Federal University of Rio de Janeiro.

*** Full Professor of Biochemistry, School of Dentistry of Piracicaba, State University of Campinas.

**** Professor, Department of Cariology and Endodontics, University of Copenhagen (in memoriam).
} 
Paim S, Modesto A, Cury JA, Thylstrup A. Development and control of caries lesions on the occlusal surface using a new in vivo caries model. Pesqui Odontol Bras 2003;17(2):189-95.

use of in vivo models for studying the development of the enamel lesion under experimental conditions s, $^{1,12,13,19,20}$ is interesting, because the lesion may be studied in a vital tooth and demineralization and remineralization can be evaluated in teeth with a known history of de-remineralization time, the patient's age and exposure to fluoride ${ }^{16,17}$.

Most of those models, until then, were prepared for smooth surfaces. Orthodontic bands cemented on homologous premolars, indicated for extraction for orthodontic reasons, showing fissures or gaps on the vestibular surface, have been used to promote the accumulation of dental plaque $e^{1,12,13,15}$, to verify the reactions of the enamel to cariogenic challenge on that surface.

The experiments conducted with those models proved that, after three and four weeks of uninterrupted cariogenic challenge, different degrees of opacities were seen clinically. However, in polarized light and under scanning electron microscopy (SEM), after one week of microbial accumulation, there were clear alterations in the tissues and in the enamel surface, respectively ${ }^{12,15,19}$.

Ever since the classic study of Dirks ${ }^{10}$, in 1966, it has been confirmed that the environmental factor plays an important part in the development of the caries process. In that study, the disappearance of white spots on the smooth and occlusal surfaces was considered to occur because of remineralization or abrasion of the surface. Longitudinal clinical research found that, when incipient lesions formed around orthodontic brackets were submitted to dental plaque control (DPC), there was a gradual change in the appearance of the lesions, from opaque-white to a more diffuse opacity. It is believed that the regression of the incipient enamel lesion, at a clinical level, can occur primarily through abrasion of the surface due to the action of intra-oral mechanical forces and through reinstatement of the mechanical removal of dental plaque ${ }^{5,6}$.

Holmen et al. ${ }^{13}$ (1987a) worked on four premolars of four patients who adopted the usual oral hygiene and the same dietetic standard, while the fluoride was controlled in the study. The bands were removed four weeks later, one tooth was extracted immediately and the others after one, two and three weeks of re-exposure to the oral environment. The formation of a white spot was noted after four weeks of cariogenic challenge. However, after re-exposure, the test teeth gradually became whiter and showed a reduction in the opacity of the damaged surface. Under SEM, a gradual reduction was noted of the layers of crystals dissolved with the progression of the exposure time, increasing the tissue scars and the surface smoothness. Polarized light examinations revealed less tissue porosity, especially in the deep part of the lesions, while the surface layer was more porous than at the base of the lesion ${ }^{14}$.

Holmen et al. ${ }^{15}$ (1988) used the same type of in vivo caries model. The control teeth were submitted to five weeks of uninterrupted microbial accumulation while the test teeth were carefully cleaned with a cotton swab or polished weekly during five weeks, using non-fluoridated toothpaste. Visible signs of carious dissolution were found on the control surfaces of all the individuals and confirmed under polarized light by the increase of tissue porosity, showing classic subsurface lesions in different stages of progression. On the other hand, weekly professional control during five weeks on the test teeth was able to prevent the progression of the lesion, regardless of the cleaning procedure used. The authors concluded that regular mechanical removal of dental plaque is capable of preventing bacterial activity and the development of the caries lesion.

Based on previous studies ${ }^{1,12,14,15,16}$ that used in vivo caries models prepared for smooth surfaces, the aim of this research was to develop a new in vivo model for the occlusal surface. The clinical and microscopic characteristics of occlusal surfaces submitted to a cariogenic challenge in vivo and subsequent dental plaque control were described.

\section{MATERIALS AND METHODS}

This study was revised and approved by the Ethics Committee, Nucleus of Collective Health Studies, Federal University of Rio de Janeiro. The person responsible for each individual signed a statement of free and conscious consent, authorizing the individual's participation in the research, after being informed about the methodology and objectives of the research, its risks and benefits.

Four volunteers took part in this study, aged from 12 to 15 years. Each volunteer contributed with one pair of homologous first premolars (PM) $(8$ premolars) indicated for extraction for orthodontic reasons. The volunteers were not participating in any program involving the use of fluoride or chemical antiplaque agents during the experiment and resided in an area where there is a very low con- 
Paim S, Modesto A, Cury JA, Thylstrup A. Development and control of caries lesions on the occlusal surface using a new in vivo caries model. Pesqui Odontol Bras 2003;17(2):189-95.

centration of fluoride (0.02 to $0.19 \mathrm{ppmF})$, which was confirmed previously in biochemical tests.

The occlusal surface of the selected teeth did not show clinical signs of carious lesions, opacities or restorations. In order to eliminate the action of mechanical forces of mastication and the functional occlusion of the selected teeth, their antagonists were extracted before starting the study, according to the volunteer's orthodontic planning. A wire mesh was bonded on the occlusal surface to create a space for promoting the accumulation of dental plaque. The mesh reached the edges of the mesial and distal crests in an anterior-posterior direction, as far as the beginning of the buccal and palatine or lingual aspects (Figure 1).

Initially, the surfaces were polished with pumice stone and water during 10 seconds and the region of the test tooth was relatively isolated. The enamel was conditioned only on the crests and at the beginning of the buccal and palatine (or lingual) aspects with phosphoric acid gel during 15 seconds, washed during 30 seconds and dried with an oil-free air jet. A bonding agent was applied (Single Bond, 3M do Brasil, São Paulo, Brazil) and light-cured during 20 seconds. The mesh was previously adapted to the surface and a composite (Z100, 3M do Brasil, São Paulo, Brazil) was placed at its ends incrementally and then light-cured for 40 seconds. The phosphoric acid, the bonding agent and the composite were applied carefully, to avoid jeopardizing the test surface.

All the volunteers used non-fluoridated toothpaste and were told not to brush the experimental surfaces, not to use anti-plaque agents and not to drink black tea during all the experiment. After

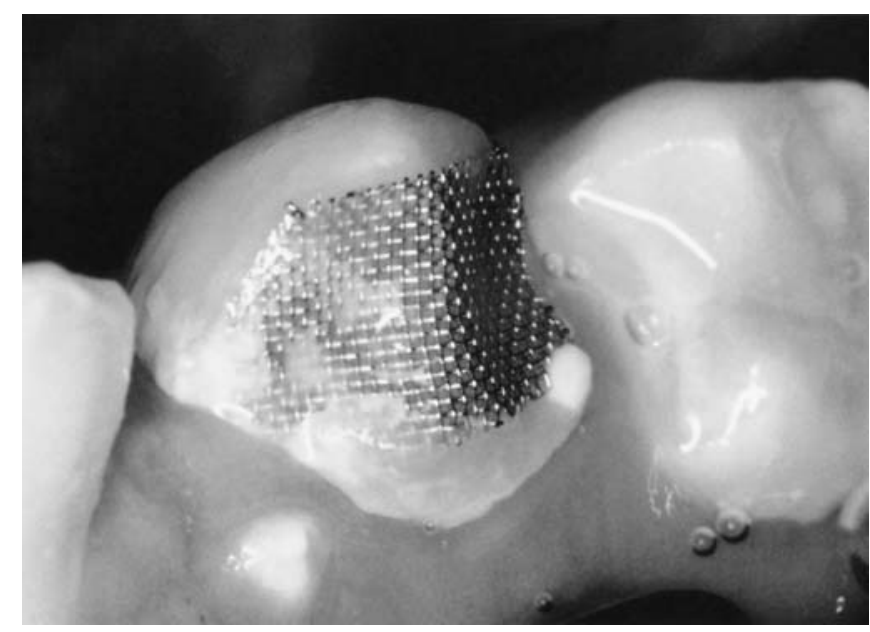

FIGURE 1 - Wire mesh bonded to occlusal surface for promoting dental plaque accumulation. four weeks, all the meshes were removed. After prophylaxis, a single examiner inspected and evaluated all the test surfaces. Notes were made about the presence or not of opacities on the surface, as well as the levels found (none, discreet opacities and well-defined opacities). The examination was not standardized because the intention was to analyze qualitatively the differences of development of the caries lesion and its control. Subsequently, the test surfaces were re-exposed to the oral environment and submitted to mechanical dental plaque control (MDPC).

The teeth were distributed in four groups, with two premolars each. In the first and third groups, the teeth were submitted to two weeks of MDPC, which was carried out daily by the individual in group 1, and daily by the individual and weekly by the professional in group 3, using the same non-fluoridated toothpaste. In the second and fourth groups, MDPC was carried out during four weeks, daily by the individual in group 2 , and daily by the individual and weekly by the professional in group 4. After the determined periods, the teeth were extracted according to Figure 2.

After the extractions, the teeth were stored in a 4\% pH 7.4 formaldehyde solution and later photographed under the stereoscopic magnifying glass. The crowns were sectioned buccolingually in a microtome for hard tissues. The cuts were directed to the region of the fossa and central groove of the premolar, preferably in areas where there were visible opacities. Initially, the cuts showed a thickness of 120-170 $\mu \mathrm{m}$. The specimens chosen were filed with a water file no. 600 and polished with a water file no. 1200 until a final thickness was obtained between 80-100 $\mu \mathrm{m}$, which was the thickness indicated for examination under a polarized light microscope (Carl Zeiss). Qualitative examinations were obtained using as a soaking means water, air and cedar oil, according to the evaluation method of Thylstrup et al. ${ }^{18}$ (1976).

\section{RESULTS}

\section{Macroscopic evaluation of surfaces}

After four weeks of local cariogenic challenge, all the occlusal surfaces showed clinical signs of mineral loss in different degrees, from light opacities to white spots. When the mesh was removed and the MDPC was reinstated on the test surfaces, increased brightness and enamel translucency were noted, directly proportional to the time of 
Paim S, Modesto A, Cury JA, Thylstrup A. Development and control of caries lesions on the occlusal surface using a new in vivo caries model. Pesqui Odontol Bras 2003;17(2):189-95.

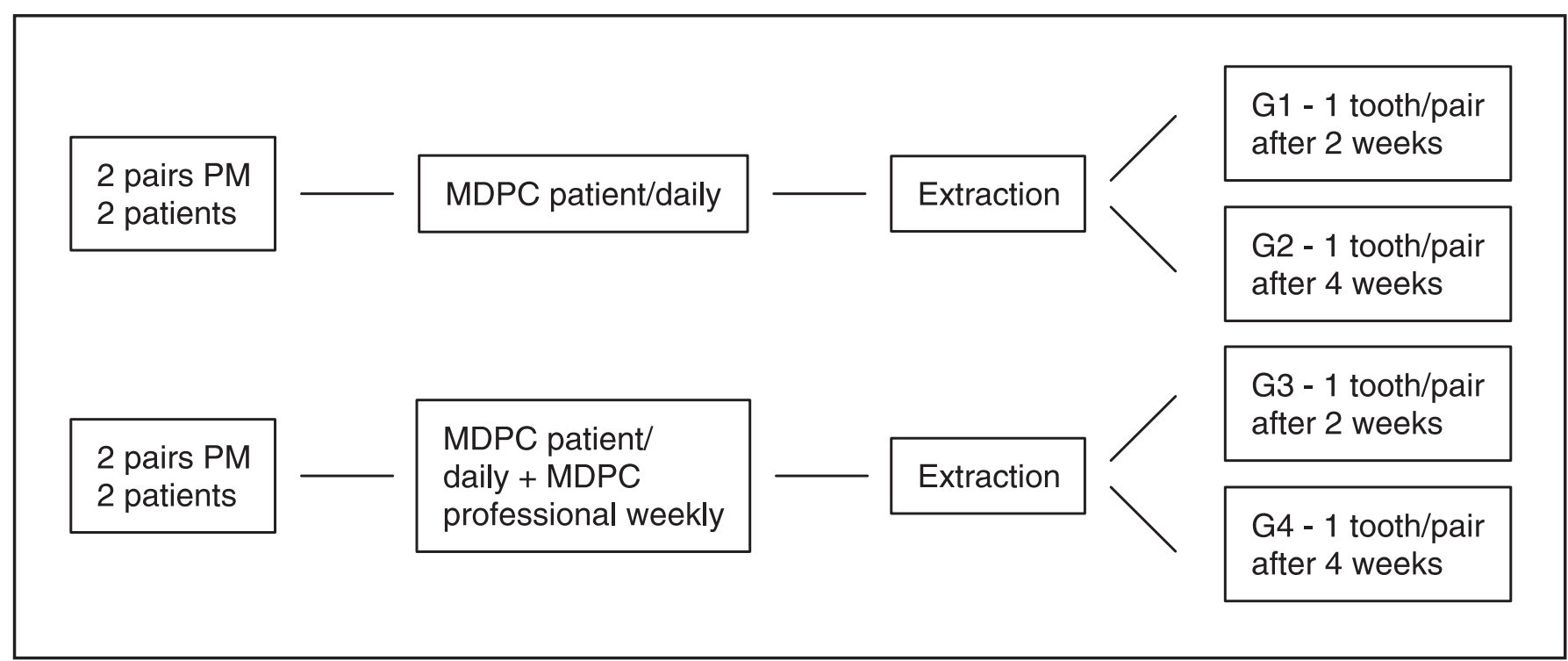

FIGURE 2 - Reinstatement of control of plaque and distribution of the periods for the extractions. PM = first premolars; $\mathrm{MDPC}=$ mechanical dental plaque control; $\mathrm{G}=$ group.

MDPC. After four weeks of MDPC, the lesion had regressed in most of the individuals.

Clinically, no difference was perceived between the two types of therapy (daily MDPC done only by the patient and MDPC done by the patient daily associated to weekly professional prophylaxis), according to the evaluation periods proposed in the methodology of this study.

\section{Microscopic evaluation under polarized light}

The qualitative evaluations confirmed the clinical observations that not all the individuals responded similarly, after four weeks of cariogenic challenge. Variations in the tissue porosity were found among the individuals, ranging from pseudoisotropic lesions to classic enamel lesions.

Differences were noted between specimens submitted to two and four weeks of MDPC. Greater tissue porosity was found in specimens submitted to two weeks of MDPC. The tissue reactions varied from well-defined dark zones to classic enamel caries lesions. The specimens submitted to four weeks of MDPC showed smaller tissue reactions compared with those of the previous period, which were suggestive of control of demineralization on those surfaces (Figures 3 and 4).

However, in specimens of one individual submitted to the second treatment, classic enamel caries lesions were seen after two and four weeks of MDPC, revealing quick progression of the lesion during the time the surface was protected by the mesh. This characteristic was observed clinically as a broad white mark. Under polarized light, those lesions presented a well-defined superficial layer, showing negative birefringence and the body of the lesion, which represented the area of greatest tissue loss, presenting positive birefringence (Figure 5). Nonetheless, although those microscopic reactions were marked in that individual, in both periods it was found, clinically, that the brightness recovered with the increase of the time of exposure of the surface to the oral environment and to MDPC.

\section{DISCUSSION}

Based on knowledge of in vivo caries models for smooth surfaces, a new model was developed in this research to induce in vivo demineralization on the occlusal surface. It was decided to evaluate the alterations noted in the human occlusal enamel in a situation of intense cariogenic challenge, describing them qualitatively from the clinical and microscopic viewpoints. That justifies the $\mathrm{n}$ (number of subjects) used, corroborating similar methodologies found in the literature $e^{3,5,6,12,13,15,16,19}$.

After four weeks of uninterrupted cariogenic challenge, different degrees of opacities were noted on the test surfaces, agreeing with the observations of studies made on smooth surfaces ${ }^{5,6,12,13,14,15}$. Similarly to this research, there was no standardization of the clinical evaluation in those studies because they also envisaged an individual, 
Paim S, Modesto A, Cury JA, Thylstrup A. Development and control of caries lesions on the occlusal surface using a new in vivo caries model. Pesqui Odontol Bras 2003;17(2):189-95.

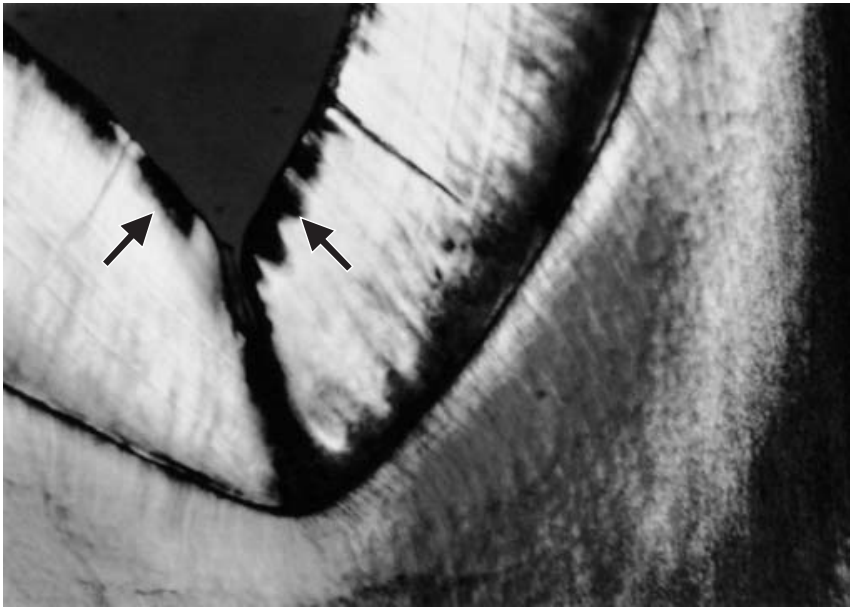

FIGURE 3 - Specimen of an individual after 2 weeks of mechanical dental plaque control - subsurface lesion showing well-defined dark zone.

non-comparative qualitative analysis of the clinical findings.

Two treatments were conceived to illustrate the response of the induced caries lesion in the proposed model. In the first, the daily MDPC was done by the individual exclusively and, in the second, by the individual (daily) and weekly by the professional during two and four weeks after re-exposure of the test surfaces.

After reinstating the MDPC, fast remineralization of the demineralized tissue took place, seen as increased whiteness of the surface and clinical regression of the lesion or reduction of the tissue porosity, which were directly proportional to the time of MDPC proposed in this experimental scheme. The reduction of microbial activities through MDPC on the test surfaces seems to have been decisive for obtaining the clinical and microscopic findings in this research, considering that the use of fluoride was controlled in the study, as noted in earlier findings $s^{5,6,14,15}$.

Fluoride plays an important role in controlling caries development, and its principal sources of daily exposure should be controlled. The two principal sources, water and toothpaste, were controlled in this study. However, fluoride does not avoid caries development, but rather reduces the speed of its progression, as found in studies with in vivo and in $s i t u^{8,19}$ experimental intra-oral models. Therefore, the absolute control of fluoride was not crucial, because the proposal of this research was to qualitatively describe the characteristics present.

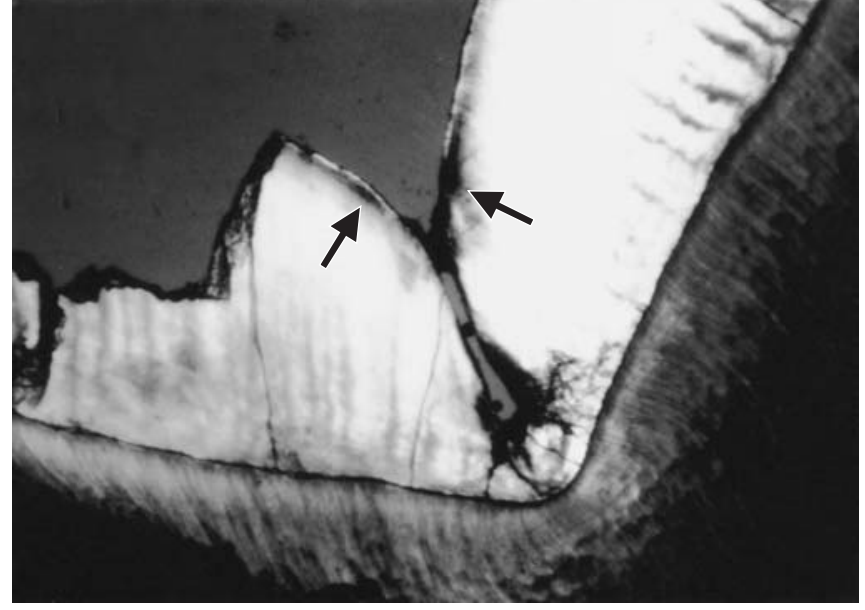

FIGURE 4 - Specimen of an individual after 4 weeks of mechanical dental plaque control - subsurface lesion showing lower proportion of tissue porosity, compared with the lesion of Figure 3.

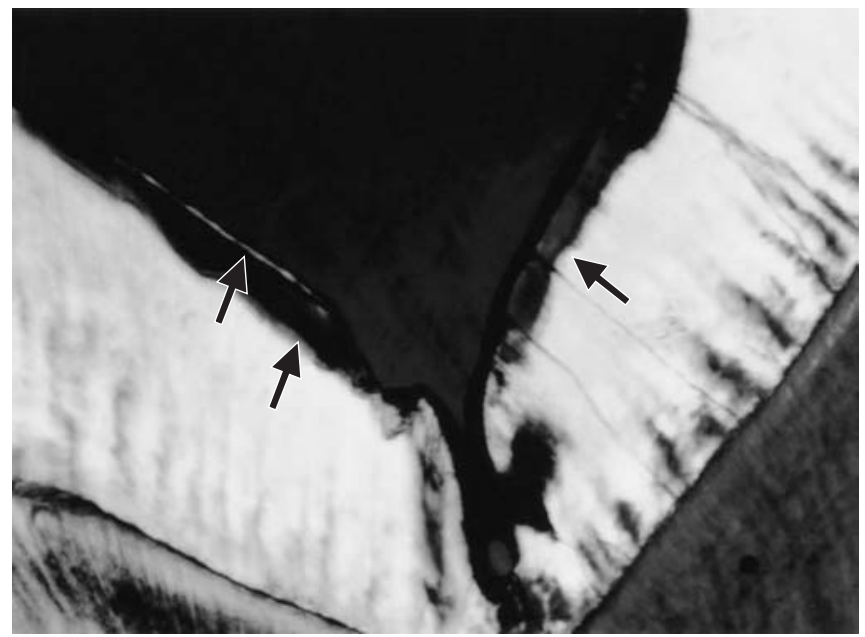

FIGURE 5 - Specimen of an individual who showed rapid progression of a caries lesion after 4 weeks of dental plaque accumulation - body of lesion showing positive birefringence - superficial layer showing negative birefringence.

Additionally, the action of fluoride in the lesion's development occurs mainly in places where the cariogenic challenge is moderate ${ }^{17}$, which does not happen in the proposed model. Since we found a clinical situation of severe plaque accumulation ${ }^{8}$ in the caries risk groups, the new model developed may contribute toward testing the cariostatic activity of fluoridated agents under severe cariogenic challenge on the occlusal surface.

The microscopic alterations found in this study under polarized light were similar to those obtained by Holmen et al. ${ }^{14}$ (1987b). In their research, 
Paim S, Modesto A, Cury JA, Thylstrup A. Development and control of caries lesions on the occlusal surface using a new in vivo caries model. Pesqui Odontol Bras 2003;17(2):189-95.

the authors used a similar methodology and less tissue porosity was noted in the specimens submitted to a longer MDPC time. Well-defined dark zones and pseudoisotropic areas were observed, which indicated a smaller amount of mineral loss. The superficial layer of the lesion was small and very often nonexistent, similarly to the findings of Holmen et al. ${ }^{15}$ (1988).

In the individual who showed fast progression of the carious lesion after four weeks of cariogenic challenge, the zones of enamel carious lesion were observed under polarized light and they were similar to those described by Darling ${ }^{9}$ (1958). In that individual, the fast development of the lesion, during the period when the surface was protected by the mesh, suggests the effect of insufficient oral hygiene, presented during all the period of the study. In spite of this, at the end of the experiment, the enamel translucency had increased, indicating arrestment of the lesion. As he received the second treatment, the weekly professional plaque control may have played an important role in arresting the lesion, identified through the recovery of whiteness, at the clinical level.

Furthermore, the weekly professional MDPC done on smooth surfaces in in vivo caries models seems to maintain, at subclinical levels, control of the tissue porosity, avoiding the progression of the mineral loss in a situation of local cariogenic challenge ${ }^{15}$. From a clinical viewpoint, this might explain the effectiveness of the regular removal of dental plaque in the control of the incipient occlusal carious lesion, particularly during the critical eruption $\operatorname{period}^{4,7}$.

The differences of progression of the lesion among the individuals, observed clinically, were confirmed through polarized light microscopy. At the microscopic level, they were revealed as different degrees of tissue porosity in various specimens submitted to the same period of local cariogenic challenge. Extrapolating these results to a clinical view, the importance of a global diagnosis of the individual is confirmed. This is essential for devising individual strategies that are coherent with the real necessities of professional activity ${ }^{2}$.

Easy implementation, low cost, the volunteer's cooperation not being an important factor and, principally, the determination of a severe cariogenic challenge on the test surface leading to demineralization contributed toward positive results of the model proposed in this study. However, the difficulty of obtaining a sample is a factor for concern in experimental intra-oral models ${ }^{17}$.
In view of the promising results of the new model shown in this study, future studies, not only qualitative but quantitative under polarized light microscopy, SEM and microradiography, should be carried out, for example, to test the clinical caries-preventive effect of treatments based on fluoride or other agents on the occlusal surface, to analyze the microbiological aspects, to compare the reactions of the enamel on smooth and occlusal surfaces in a situation of retention and control of dental plaque etc. Therefore, new research using this experimental model will make it possible to validate the results obtained, helping to assess in vivo the reactions of the enamel to cariogenic challenges on the occlusal surface.

\section{CONCLUSIONS}

1 . When using the new in vivo caries model proposed for the occlusal surface, the absence of mechanical forces, specifically brushing and mastication, was the principal factor for the arrestment of the dental plaque and, consequently, for initiating the caries lesion on the occlusal surface.

2 . The new in vivo caries model was effective because all the occlusal surfaces presented clinical and microscopic signs of mineral loss in different degrees after four weeks of local cariogenic challenge.

3. After the reinstatement of mechanical control of dental plaque on the test surfaces, the demineralized tissue was quickly remineralized, which was directly proportional to the time of mechanical control of the dental plaque.

\section{ACKNOWLEDGMENTS}

This study is part of the first author's dissertation presented as one of the requirements for obtaining the title of Master of Pediatric Dentistry, School of Dentistry, Federal University of Rio de Janeiro, where Prof. Dr. Anders Thylstrup, Professor of the Department of Cariology and Endodontics, University of Copenhagen/Denmark, played an active part in outlining the study, having passed away in May 1999. We would also like to thank Mr. Waldomiro Vieira Filho (Oral Biochemistry/School of Dentistry of Piracicaba FOP/UNICAMP), Prof. Marinês Nobre S. Uchôa, Prof. Raquel Gerlach and Prof. Sérgio Line (FOP/UNICAMP) for their valuable help in the laboratorial phase of this study. 
Paim S, Modesto A, Cury JA, Thylstrup A. Development and control of caries lesions on the occlusal surface using a new in vivo caries model. Pesqui Odontol Bras 2003;17(2):189-95.

\section{REFERENCES}

1. Arneberg P, Ögaard B, Scheie AA, Rölla G. Selection of Streptococcus mutans and lactobacilli in an intra-oral human caries model. J Dent Res 1984;63:1197-200.

2. Anusavice KJ. Efficacy of non-surgical management of the initial caries lesion. J Dent Educ 1997;61:895-905.

3. Arends J, Jongerbloed W, Ögaard B, Rölla G. SEM and microradiographic investigation of initial enamel caries. Scand J Dent Res 1987;95:193-201.

4. Arrow P. Oral hygiene in the control of occlusal caries. Community Dent Oral Epidemiol 1998;26:324-30.

5. Artun J, Thylstrup A. Clinical and scanning electron microscopic study of surface changes of incipient caries lesions after debonding. Scand J Dent Res 1986;94:193-201.

6. Artun J, Thylstrup A. A 3-year clinical and SEM study of surfaces of carious enamel lesions after inactivation. Am J Orthod Dentofacial Orthop 1989;95:327-33.

7. Carvalho J, Ekstrand K, Thylstrup A. Results after 3 years of non-operative occlusal caries treatment of erupting permanent first molars. Community Dent Oral Epidemiol 1992;20:187-92.

8. Clasen ABS, Ogaard B. Experimental intra-oral caries models in fluoride research. Acta Odontol Scand 1999;57:334-41.

9. Darling AI. Studies of the early lesion of enamel caries. Brit Dent J 1958;105:119-35.

10. Dirks OB. Posteruptive changes in dental enamel. J Dent Res 1966;45:503-11.

11. Gorelick L, Geiger A, Gwinnett J. Incidence of white spot formation after bonding and meshing. Am $\mathrm{J}$ Orthod $1982 ; 81: 93-98$
12. Holmen L, Thylstrup A, Ögaard B, Kragh F. A polarized light microscopic study of progressive stages of enamel caries in vivo. Caries Res 1985;19:348-54.

13. Holmen L, Thylstrup A, Artun J. Surface changes during the arrest of active enamel carious lesions in vivo. A scanning electron microscope study. Acta Odontol Scand 1987a;45:383-90.

14. Holmen L, Thylstrup A, Artun J. Clinical and histological features observed during arrestment of active enamel carious lesions in vivo. Caries Res 1987b;21:546-54.

15. Holmen L, Mejare I, Malmgren B, Thylstrup A. The effect of regular professional plaque removal on dental caries in vivo. A polarized light and scanning electron microscope study. Caries Res 1988;22:250-6.

16. Ögaard B, Rölla G. The in vivo orthodontic meshing model for vital teeth and the in situ orthodontic meshing model for hard-tissue slabs. J Dent Res 1992;71:832-35.

17. Ögaard B, Röller G. Intra-oral models: comparison of in situ substrates. J Dent Res 1992;71:920-3.

18. Thylstrup A, Fejerskov O, Larsen MJ. Polarized light microscopy of enamel structure in incisors from newborn infants. Scand J Dent Res 1976;84:243-54.

19. Thylstrup A, Boyar RM, Holmen L, Bowden GH. A light and scanning electron microscopic study of enamel decalcification in children living in a water-fluoridated area. J Dent Res 1990;69:1626-33.

20. Thylstrup A, Bruun C, Holmen L. In vivo caries models mechanisms for caries initiation and arrestment. Adv Dent Res 1994;8:144-57. 